\title{
Kate Atkinson: Plotting to Be Read
}

\section{Glenda Norquay}

In a review of Kate Atkinson's 2015 novel, $A$ God in Ruins, Lesley McDowell asks whether her 'warm and approachable characters [and] her smart ... funny ... compassionate prose count against her when it comes to intellectual literary awards like the Booker? Even the new literary prize, the Folio, ignored the more experimental Life After Life.'1 While literary innovation need not be assessed by prize-winning recognition, accessibility is a key aspect of Kate Atkinson's fiction. Working in genres that might be defined as popular (or at least familiar to a wide readership)—detective fiction, family saga, English country house fiction, historical fiction-she writes novels that deeply engage the reader in emotions, plots and characters, so as to make for a pleasurable, joyful, moving, affirmative and affective reading experience. From her early fiction onwards Atkinson has demonstrated a 'postmodern' interest in the ontological, in 'world-making and modes of being'. ${ }^{2}$ In her first novels that was expressed in explictly experimental strategies. In her later writing she inhabits narrative convention more comfortably while simultaneously challenging them in more fundamental ways. In its underlying challenges to normative understanding of being in the world her fiction has has grown in daring

Through charting the shifts in her deployment of different fictional forms, this essay suggests that Atkinson's emphasis on plotting, which emerges in the combination of familiar and defamiliarizing constructions of 'events' and 'characters', is part of a strategic attempt to produce novels that can be pleasurable and 
meaningful yet disruptive in their challenges to our thinking about time, history, justice and love. Atkinson's trajectory of experimentation and her unique pattern of generic shifts, from the 'Case Histories' series to the recent Life After Life (2013) and A God In Ruins (2015), ${ }^{3}$ reveals that although her novels have been described as combining an interest in 'history, family and identity within a postmodern aesthetic', the increasing sophistication of that dynamic has made them both more complex and more commercially successful. ${ }^{4}$

Kate Atkinson's first novel, Behind the Scenes at the Museum (1995), was an immediate success, an acclaimed first novel easily situated within a 1990s interest in both metafiction and the historical. ${ }^{5}$ It also offered an analysis of the determinantsfamily, location, culture and imagination-of the individual life that is touching, comic and more traditionally associated with the concerns of realist fiction. Since then she has maintained an interest in the shaping forces of historical moments and individual lives, as in Human Croquet (1997) and Emotionally Weird (2000), but has developed increasingly innovative but compelling fictional forms through which to explore these concerns. ${ }^{6}$ Written at the turn of the twenty-first century, Emotionally Weird articulates a tension central to Atkinson's fiction and indicates the emergence of changing interests with the new millennium and its re-evaluation of historical formations. Through the device of a university literature tutorial, she rehearses a familiar opposition between post-structuralist thinking (Archie McCue's pontifications on 'the autonomous work of fiction') and traditional humanist perspectives (Professor Cousin's suggestion that 'all literature is about the search for identity, [and] the meaning of life') before producing a novel that conforms to neither literary agenda. ${ }^{7}$ Her later novels—-postmodern and realist, interrogating and mocking grand narratives while clinging to notions of truth and value associated with a more 
conventional humanism—work to accommodate but move beyond these apparently conflicting notions of fiction.

Atkinson's highly successful and innovative explorations of these tensions can be traced though 'Case Histories', a group of novels which, by playing with 'mystery' and telling their stories in interweaving, overlapping narratives, ironize understanding of a shared human condition but nevertheless endorse the value of an individual life. Deploying comedy and tragedy with equal effect, Atkinson finds in crime fiction a genre that allows her to engage with agency and chance, justice and retribution, and to explore tensions between social institutions and the individual imagination. The serial nature of these novels featuring Jackson Brodie-Case Histories (2004), One Good Turn (2006), When Will There be Good News (2008) and Started Early, Took My Dog (2010)—reinforces the ironic engagement with genre fiction suggested by the 2006 novel's subtitle, 'A Jolly Murder Mystery', and provides extended opportunity to examine the plotting of the self in wider narratives. ${ }^{8}$

Atkinson's more recent twenty-first-century novels, Life After Life and A God In Ruins, abandon the playful dynamic with popular forms and return to her earlier concerns with the life in history. With her focus on both the First and Second World Wars, and in that respect on the 'historical', Atkinson combines impressive research into under-narrated aspects of that period, while openly acknowledging her inheritance from E.M. Forster and Virginia Woolf. In that sense, as with 'Case Histories' and its interaction with detective fiction, they work to defamiliarize a recognized literary mode, producing deeply unsettling experience for their readers through experiments with chronology. With their combination of innovation and familiarity the novels address complex questions about the nature of history, the value of human relationships and the response of the self to the darkest of moments. In each tour de force of experimental writing Atkinson retains that compelling and 
characteristic engagement with each individual life but uses the plotting of the self to explore the subject within larger historical narratives.

Atkinson's first crime novel, whose title Case Histories (2004) then became the overarching name for a television series bringing together all the 'Jackson Brodie' novels, is fundamentally interested in and structured by the relationship between apparently random forces and the making of narrative patterns through the tragedies and triumphs of individual lives. ${ }^{9}$ Although she dislikes the label 'crime fiction', its central character, Jackson Brodie, acts in pursuit of a number of mysteries, or 'case histories'. ${ }^{10}$ In When Will There Be Good News?, One Good Turn and Started Early, Took My Dog, Brodie acts as a catalyst for each novel's adventures, becomes unwittingly implicated in them and attempts to 'solve' their mysteries. A dominant question that emerges from the novels is: can there such a thing as an 'innocent bystander'? Levels of public engagement with crime are mocked in One Good Turn when all witnesses questioned after a road rage incident can describe the dog involved but not the car registration number. In Started Early, Took My Dog, Jackson, frequently positioned as observer, is enmeshed in a plot hinging upon the complicity of inaction as much as action. 'Is anyone really a bystander?' he asks, suggesting 'you could say that we are all bystanders' (SE, 238). As Atkinson explores the complexities of retribution and justice, the relationship between victimhood and communal human responsibility, 'Case Histories' introduces characters who are victims, perpetrators, detectives, figures of retribution and apparently innocent bystanders, increasingly blurring the lines between these demarcations. While navigating the relationship between narratives of personal tragedy and the public spheres of criminal investigation and legal justice, Atkinson also poses larger questions about agency and determinism. 
In the context of contemporary Scottish writing, crime fiction has a wellestablished reputation for addressing social and political issues. ${ }^{11}$ Atkinson herself notes the pleasure of 'taking stock elements and then playing around with them.' More interestingly she adds: 'Mainstream crime is very end-driven: there's a plot that goes directly from $A$ to $B$, and all the detective is doing is going about picking up clues. That's important, but it's not what these books are about. The interesting thing to me is character. ${ }^{12}$ One way in which Atkinson works to subvert the dominant modes of crime fiction is indeed by the detailing of character: this is achieved less through narrative exposition but with the iteration of details which add specificity so that each individual life, each victim, is delineated. The first and most striking example of this is in Case Histories, where Theo Wyre returns again and again to what made his murdered daughter, Laura, herself: 'Laura, who slept curled up in a ball, who liked hot buttered toast and all the Indiana Jones movies but not Star Wars, whose first word was 'dog', who liked the wind but not the rain, who planned to have three children, Laura who would forever be standing by the photocopier in the office in Parkside waiting for the stranger and his knife' $(\mathrm{CH}, 38)$. Atkinson thus exploits realism, the appeal of knowable character, to make the reader feel loss. This recovery of a self is articulated as an impulse of literary realism but that of an ethics of 'detection'.

Detection is thus given a moral imperative. 'Inside Jackson', we are told, 'there remained a belief—a small, battered and buried belief—-that his job was to help people to be good rather than punish them for being bad' $(\mathrm{CH}, 81)$. This drive, counter to the punishment thrust of conventional crime fiction, illuminates the structuring principle of Atkinson's texts: an emphasis on the individual and the fragile possibility of creating a positive narrative. Atkinson's 'case histories' work in contradictory directions. On the one hand they suggest that violence is random, that 
chance makes people victims, damaged or lost; and on the other, that the patterns that emerge from violence suggest the possibility of 'balance' rather than justice. Jackson mentally tallies his lost and found accounts—dead daughter, missing sister, murdered sister, lost daughter-but by the end of the first novel a daughter has been replaced and a sister in some ways 'compensated' for the lost of another. This is not the justice of the symbolic order: when Jackson finds out the name of Laura's killer he puts it on a card to Theo rather than tell the police; he does not tell both sisters what happened to Olivia and Sylvia's role; he never finds out whether Nicola Spencer is having an affair. But although the narratives appear to depend upon chance, there is tangential acknowledgement of underlying explanations: Laura's deployment of her father's name actually leads to the stalker looking for her father, then murdering her; Victor's abuse of Sylvia means she descends into madness, hears voices and murders her sister, his daughter, so that he has to conceal the body, a punishment both for him and Sylvia in terms of loss and complicity. Cause and effect may be unexpected and continually ironized but also impossible to ignore. Jackson's own position meanwhile also rests upon contradiction: he 'liked to think truth was an absolute but maybe that just made him into a tight-arsed moral fascist' $(\mathrm{CH}, 318)$

Atkinson's subsequent novels in this series more confidently parody the crime genre. In One Good Turn Martin, the mild-mannered surprise hero of the opening scenes is himself a crime writer, producing novels that he thought were pastiches of the 'old-fashioned soft-boiled' genre of the 1940s but in fact have been successfully marketed as 'jolly murder mysteries' and turned into a television series: 'Perfect fodder for the Sunday evening slot, the BBC producer said, making it sound like an insult, which of course it was' (OGT, 20). Equally heroic housewife Gloria in the same novel 'had no enthusiasm for crime writing. It had sucked the life out of her 
father, and anyway wasn't there enough crime in the world without adding to it, even if it was fictional?' (OGT, 37). In Started Early, Took My Dog, minor character, Marilyn Nettles, is a writer of 'true noir' fiction: "Women in Jeopardy", she commented, handing Jackson a mug of coffee. 'Very popular. You have to wonder' (SET, 250).

As this comment suggests, the intersections of women's lives and criminality become an increasing focus of attention in the series. Without asserting an explicitly feminist agenda, each novel's plot revolves around missing or lost women and the challenges faced by women who are not lost. One Good Turn and When Will There be Good News continue the unfulfilled relationship, dogged by bad timing, between police detective Louise Murdoch, locked into the system, and the outsider, Jackson Brodie. While differing in their missions, both are shown to operate in the same arena defined by the victimhood or not of women. Jackson, we are told, "cared about missing girls, he wanted them all found. Louise didn't want them to get lost in the first place' (WWT, 170). When Will There be Good News examines the possibilities but also the dangers of women enacting justice for themselves. By contextualizing its plot through the 1970s and Ripper murders Started Early, Took My Dog situates Jackson's search 'for all the lost girls' within a more specifically historicized understanding of women in jeopardy: 'The past was a dark place, a man's world' (SET, 329). As the power to enact justice increasingly comes from outside the law, Jackson becomes feminized both by his apparent powerlessness and his need to redress justice through private means: "The older you get, the more like a woman you become", Julia said' (SET, 50).

Atkinson's self-conscious relationship to crime writing, part of her broader gesture towards postmodernism, means that her attention to individual character is balanced by a knowingness about self-fashioning. In One Good Turn the sinister 'Ray', who 
has invented his name because he likes its ambiguous possibilities and because he likes slipping between identities, is positioned against Martin, who has little control in formulating his own identity, leaving that to his father, and to his publisher whose insistence that he was a monk then becomes the fulcrum of interviews even as he denies it (OGT, 22). But rather than an easy questioning of the 'fictions' of identity, Atkinson's novels use the plotting of selves and the careful chronologies of crime writing to raise much larger questions around agency, historical determinism, the nature of victimhood and survival. The 'Case Histories' series, as its first title suggests, attempts to make sense of different moments in time and the connections between them, an interest extended by Atkinson's subsequent novels.

In Case Histories this interest in temporality is evident through highly specific dates, increasingly given meaning in relation to each other. One Good Turn is organized around days, while in When Will There be Good News the different sections of the novel are 'The Past', 'Today', 'Tomorrow', 'And Tomorrow'. Started Early, Took My Dog is structured in more abstract terms-Treasure, Sacrifice, Jeopardy_but again moves backwards and forwards in time, returning to the Yorkshire Ripper murders of the 1970s. In One Good Turn a character reflects: 'That was how history worked, wasn't it? If it wasn't written down it never existed. You might leave behind jewellery and pottery, ornamental tombs, you might leave behind your own bones to be dug up in a later age, but none of those artefacts could explain how you felt' (OGT, 96). All these novels explore how 'feeling' might be understood within time, what makes for a 'valuable' life, and what are the forces that might determine the feelings of an individual. This interest in chronology and temporality becomes increasingly complicated in Atkinson's later fiction. A God In Ruins has Teddy asking Bertie to 'promise to make the most of your life' but Bertie 'already at twenty-four knowing it was unlikely she would be able to do so' (AGR, 
112). In Life After Life Ursula states: 'I believe we have just one life and I believe that Teddy lived his perfectly' ( $L A L, 376)$.

The 'Case Histories' series also shares with the later novels a fascination with the ways in which narratives of 'perfection' shape desires and feelings and are expressed in fantasies of both time and place. These novels anticipate Atkinson's later interest in versions of Englishness, possessing a dominant power in the literary imagination, set in stark contrast to the Scottish or Northern English landscapes which construct their settings. When Martin in One Good Turn worries why everyone doesn't live in the world of the imagination because it is so much better than the real one, he defines the constituents of that world as: 'Scones, home-made blackcurrant jam, clotted cream. Overhead, swallows sliced through the blue, blue sky, swooping and diving like Battle of Britain pilots. The distant thock of leather on willows. The scent of hot, strong tea and new mown grass' (OGT, 21). In her most recent novels Atkinson lovingly recreates this world, symbolic of a desired social order, then brings it, if not to ruins, at least into question by positioning it within darker and more historically-inflected contexts.

While this shift towards Englishness appears to make her novels more mainstream, that lost world is presented as increasingly impossible. And their greatest challenge is of conventional temporality: by engaging with a past in before war 'when people still believed in the dependable nature of time' ( $A G R, 73)$, Atkinson develops both a structural and thematic challenges to our notions of time and history. In Life after Life Atkinson offers us plenty of signposting as to the nature of her experiment: the novel opens with an epigraph voiced by one of its characters'What if we had a chance to do it again and again until we finally got it right?', which becomes the central question in the book. Beginning in 1910 and ending, arguably, in 1967, the novel works and reworks the life possibilities of Ursula Beresford Fox, 
recreating a range of life stories that are shaped by chance, by larger historical forces, and increasingly, as she experiences a kind of déjà vu, by Ursula herself. Characters constantly pronounce on the nature of time: Sylvie, Ursula's mother, says 'we all end up in the same place', while her daughter insists that 'it's how you got there that matters' ( $L A L, 240)$. 'Hindsight is a wonderful thing', adds her friend Klara. 'If we all had it there would be no history to write about' ( $L A L, 327)$. Another character, Ursula. tells her therapist that time 'isn't circular, it's a palimpsest' ( $L A L$, 456); when a co-worker misquotes John Donne's Holy Sonnet 13, 'What if this were the world's last night?', Ursula corrects him: 'What if this present were the world's last night?', reflecting, “'The word 'present' makes all the difference, don't you think? It makes it seem as if one's somehow in the thick of it, which we are, rather than simply contemplating a theoretical concept"' $(L A L, 375)$. Key to the whole text, the question of what it means to be 'in the thick of it', has two aspects. Can one change history? And can one change the understanding of history?

Characterizing its response to both questions-how is agency to be achieved and what might historical agency actually mean in the context of a new millennium —is the novel's attentiveness to gender and the 'historicized' acquisition by women of the power to change events, embodied by developments in the period it novel covers. In the section entitled 'A Lovely Day Tomorrow', the sixteen-year old Ursula has to live through various iterations of sexual assault by a visiting American, each time responding with a more vigorous rejection and each time shaping her subsequent life as one of lesser misery, oppression and passivity. A personal history can therefore be 'remastered'. In an early version of Ursula's life the clumsy rape attempt leads to an unwanted pregnancy, disastrous marriage and drink. Only in later versions can she slap down the aggressor, escape and shape her life differently. 
Political history is less easy to determine than a personal narrative but Ursula nevertheless has a go. The novel's most obvious 'what if'-and one Atkinson herself admits inspired the novel-is what if someone shot Hitler. When one of Ursula's incarnations leads her to this point, it is a particularly gendered moment, a collision of the public and domestic. Ursula insinuates herself into Hitler's inner circle through friendship with Eva Braun, meets these powerful men in the feminized atmosphere of a German cafe, where they are indulging in hot chocolate and luscious cakes, produces a gun out of her handbag having just dabbed at her lips with a lacy handkerchief and points it at the Führer.

This is the most striking example of the way in which a 'womanly sphere' can be brought to change history but in addition to this dramatic plot device the novel frequently articulates a Woolfian awareness of the gendering of perspective and the 'difference of value'. ${ }^{13}$ When Ursula's father signs up at the outbreak of the First World War because 'it may be the only adventure I ever have' her mother shouts at him 'Adventure? ... what about your children? What about your wife?' $(L A L, 60)$ The novel continues to interrogate such rhetoric with the notion of life as an 'adventure' being set against Sylvie's idea of life as an endurance race or an obstacle course $(L A L, 180)$. Through its narrative structure, the nature of its events and in its explicit observations on time, Life After Life echoes Woolf's oft-quoted statement in 'Modern Fiction' that life is more than just 'a series of gig lamps symmetrically arranged'. ${ }^{14}$ The past may be 'a straight line for Pamela' but it is 'a jumble for Ursula' $(L A L, 70)$ : 'Her memories seemed like a cascade of echoes. Could echoes cascade?'( $L A L$, 156). The novel not only presents a challenge to gendered versions of history but begins to interrogate progressional versions of temporality.

Life After Life and A God In Ruins could be read as melding the various responses of women to history identified by Julia Kristeva in her essay Women's 
Time: the early attempts of the women's movement to gain a place in linear time, a second phase in which 'linear temporality has been almost totally refused, and as a consequence there has arisen an exacerbated distrust of the entire political dimension' and then the third phase mixing the two attitudes: 'insertion into history and the radical refusal of the subjective limitations imposed by this history's time on an experiment carried out in the name of irreducible difference' so that 'the very dichotomy man/woman as an opposition between two rival entities may be understood as belonging to metaphysics'. ${ }^{15}$ Yet ironically, given the family-focused nature of her fiction, Atkinson goes further, challenging what Judith Halberstam describes as 'the force of middle-class logic of reproductive temporality.' Halberstam argues 'in western culture, we chart the emergence of the adult from the dangerous and unruly period of adolescence as a desired period of maturation; and we create longevity as the most desirable future ... and pathologize modes of living that show little or no concern for longevity.' ${ }^{16}$ In their refusal to adhere to that model of temporality, in their playing with 'then and now' and with the dissolving of those separations, Atkinson's most recent novels partake in what Carolyn Dinshaw has described as the 'difficult work of thinking outside narrative history, reworking linear temporality. ${ }^{\prime 17}$

The novels achieve this in various ways. They do it first, and most obviously, in the very structure of their fictions. In its emphasis on a re-iterated now-ness, Life After Life could be read as a manifestation of Walter Benjamin's advocacy of 'history' as 'time filled by the presence of the now.' 18 Atkinson's most recent novel, A God in Ruins, appears to move back and forwards in time but comes to rest in a moment of present that dissolves and, to an extent, denies everything that has gone before. Secondly, her fiction provides an explicit critique of 'history as linear narrative', in the many comments about time as chaos and jumble. Life After Life 
further challenges assumptions about history in terms of a political imagination. When Ursula realizes that 'most people muddled through events and only in retrospect realized their significance; the Führer was different, he was consciously making history for the future. Only a narcissist could do that' (LAL, 324), she is offering a critique, in psychological terms, of the notion that 'politics is a name for the temporalization of desire, for its translation into a narrative, for its teleological determination'. Hitler might be read as embodying an extreme version of what Lee Edelman has described as 'the coercive belief in the paramount value of futurity'. ${ }^{19}$

If these novels critique normative temporality, they also begin to offer alternatives. Atkinson does this by focusing on death, structuring her narratives in terms of the formal repetition distinctive of the death drive. This is achieved in Life After Life by presenting many different narratives for Ursula Beresford's life, a constant movement towards her survival, towards self-realization, but with most of them ending in annihilation — with the words 'Darkness fell'-before beginning again. A God in Ruins is death-centred in a more public way, focusing as it does on the lives on Halifax bomber crews during the Second World War. As the novel progresses, the repeated accounts of bombing raids over Germany, indicating the similar yet different dangers of each raid, become representative of a 'life after life', which each time is nearer to a death. The death at the centre of these accounts both creates and annihilates the whole narrative the novel contains: Teddy's life. It also creates that moment of stop in the present-Teddy's death in the air-which then becomes the model of 'a life lived perfectly. (AGR, p. 376).

Because of their apparent realism, the focus on relationships and individuals, and their interest in the tiniest details of the everyday, Atkinson's novels could be read as constructing what Lauren Berlant describes as an 'intimate public sphere' and has condemned because of the ways in which 'questions of intimacy, sexuality, 
reproduction and the family', while properly interrelated with questions of identity and inequality, become 'over-organizing' in terms of public discussions about power, ethics and the nation.' ${ }^{20}$ Yet, arguably, what the novels and their predecessors in the 'Case Histories' series achieve is to take our engagement with these intimate spheres, our willingness to feel through character and plot, to force us as readers to develop new modes of organizing our understanding. As a result Atkinson offers her readers pleasure but never complacency. In some respects Atkinson's fiction might appear to have become less obviously 'postmodern', satisfying her readers with the kind of textual engagement familiar from a realist novel, yet they retain that impulse to 'trouble and volatize' identified with postmodernism. ${ }^{21}$ While 'plotting' remains a consistent concern, the dimensions in which it is understood have shifted to encompass larger questions about how the self might be understood in terms of past, present and future. While the 'Case Histories' series addresses hard questions about the plotting of individual and social justice and the tensions between them Life After Life and A God in Ruins struggle with the more general possibilities of plotting in a world without 'the tenses that Western civilization was constructed on'. ( $A G R$,

73)

\section{NOTES}

1 Lesley, McDowell, 'Book of the Week: A God in Ruins by Kate Atkinson': http://www.thenational.scot/culture/book-of-the-week-a-god-in-ruins-by-kateatkinson-doubleday-20.3077. Accessed 28 September 2015.

2 See Brian McHale, The Cambridge Introduction to Postmodernism

(Cambridge: Cambridge University press, 2015), p. 15.

3 All quotations are from Kate Atkinson, Life After Life (London: Doubleday, 2013) and A God in Ruins (London: Doubleday, 2015). Hereafter page numbers will be given in the text, preceded by $L A L$ and $A G R$, respectively. 
4 Fiona Tolan, "'Everyone Has Left Something Here": The Storyteller-Historian in Kate Atkinson's Behind the Scenes at the Museum', Critique: Studies in Contemporary Fiction, 50 (2009), 275-92; 276.

5 Kate Atkinson, Behind the Scenes at the Museum (London: Doubleday, 1995).

6 Kate Atkinson, Human Croquet (London: Doubleday, 1997); Emotionally Weird: A Comic Novel (London: Doubleday, 2000).

7 Emotionally Weird, pp. 38-9.

8 Kate Atkinson, Case Histories (London: Doubleday, 2004), One Good Turn: A Jolly Murder Mystery (London: Doubleday, 2006), When Will There Be Good News (London: Doubleday, 2008), Started Early, Took My Dog (London: Doubleday, 2010). All quotations are from these editions; hereafter page numbers will be given in the text, preceded by $C H, O G T, W W T$ and $S E T$, respectively.

9 The first three novels were adapted for series one of the BBC television drama 'Case Histories'. Started Early, Took My Dog formed the basis of episode one of a second series; two new stories were written for two further episodes. See 'On Screen': http://www.kateatkinson.co.uk/on screen.php. Accessed 28 September 2015.

10 See 'Interview: Kate Atkinson, Author', The Scotsman, 13 August 2010:

http://www.scotsman.com/news/interview-kate-atkinson-author-1-821075. Accessed 28 September 2015.

11 William Mcllvanney and lan Rankin were trailblazers; Louise Welsh and Denise Mina continue to explore the form's potential.

12 'Interview: Kate Atkinson, Author', The Scotsman, 13 August 2010:

http://www.scotsman.com/news/interview-kate-atkinson-author-1-821075. Accessed 28 September 2015.

13 Virginia Woolf, $A$ Room of One's Own (1929): 'But it is obvious that the values of 
women differ very often from the values which have been made by the other sex.' (London: Grafton, 1977), p. 70.

14 'Modern Fiction', in Virginia Woolf, The Common Reader, 1925 (rpt. London: Hogarth Press, 1951), pp. 184-95.

15 Julie Kristeva 'Women's Time', trans. Alice Jardine, and Harry Blake, Signs: Journal of Women in Culture and Society, 7 (1981), pp. 13-35; 19, 20, 34.

16 Judith Halberstam, In a Queer Time and Place: Transgender Bodies, Subcultural Lives (Sexual Cultures), 1st edn. (New York: New York University Press, 2004), p. 4.

17 Carolyn Dinshaw, L. Edelman, R. A. Ferguson, C. Freccero, E. Freeman, J. Halberstam et al, 'Theorizing Queer Temporalities: A Roundtable Discussion', GLQ: A Journal of Lesbian and Gay Studies, 13 (2007), 177-95; 185.

18 Walter Benjamin, 'Theses on the Philosophy of History in Illuminations, ed. Hannah Arendt, trans. Harry Zorn (London: Pimlico, 1999), p. 252.

19 Lee Edelman, No Future: Queer Theory and the Death Drive (Durham: Duke University Press, 2004), p. 6.

20 Lauren Berlant, The Queen of America Goes to Washington (Durham/ London: Duke University Press, 1997), p. 8.

$21 \quad$ McHale, Cambridge Introduction to Postmodernism, p. 15. 